\title{
Minimal Intervention Prosthodontics: Current Knowledge and Societal Implications
}

\author{
J ohn Bowley \\ Restorative Sciences Department, Faculty of Dentistry, Kuwait University Health Sciences Centre, Kuwait, Kuwait
}

\section{Key Words}

Minimal intervention - Contraindications - Limitations . Prosthodontics - Acrylic resin toxicity $\cdot$ Human resources

\begin{abstract}
Minimal intervention prosthodontics can be considered a treatment option for a country's overall dental health care plan. Prosthodontics can cover a range of increasingly aggressive treatment interventions depending on the severity and progression of the disease. The 'shortened dental arch' concept is a minimal treatment intervention approach that has been advocated for a wide range of partially edentulous patients. This concept favors limited prosthodontic intervention to achieve patient-perceived acceptable function levels in the presence of multiple missing teeth. The implementation of minimal interventions should be balanced by considering risk-to-benefit ratios, as well as the consequences of nonintervention or low-level prosthodontic interventions. The 'nonintervention' approach and low-level prosthodontic interventions have inherent consequences and well-documented risks; professional ethics dictate that a practitioner present these risks as well as the known benefits of all treatment options. Developing countries are under significant pressure to effectively uti-
\end{abstract}

lize limited resources, increase skilled human resources, provide advanced levels of care to very large numbers of patients and plan for the future dental health care of their society. Many developing countries are prime candidates for inadvertent abuse and misappropriation of prosthodontic materials, treatment modalities and human resources in trying to provide cost-effective prosthodontic care. A developing country can learn from the mistakes that developed countries have made in the past and use the evidence from these experiences to plan for a better future state of dental health for their society.

Copyright $\odot 2002$ S. Karger AG, Base

\section{Dental Health Continuum}

The purpose of this literature review is to evaluate the appropriateness of minimal prosthodontic intervention among patients with varying degrees of natural tooth loss or destruction of coronal tooth substance. Tooth loss occurs in both developed and newly developing countries as a result of dental caries, periodontal disease, trauma, neoplastic disease, developmental maladies and environmental factors. This review summarizes the literature that supports or refutes the 'minimal treatment concept' with emphasis on important gaps in this body of knowledge.

\begin{tabular}{ll}
\hline KARGER & ( ) 2002 S. Karger AG, Basel \\
Fax +4161306 1234 & 1011-7571/02/0115-0022\$18.50/0 \\
$\begin{array}{l}\text { E-Mail karger@karger.ch } \\
\text { www.karger.com }\end{array}$ & $\begin{array}{l}\text { Accessible online at: } \\
\text { www.karger.com/journals/mpp }\end{array}$
\end{tabular}

Dr. J.F. Bowley

Kuwait University Faculty of Dentistry

PO Box 24923

Safat 13110 (Kuwait)

Tel. +965 266 4502, ext. 7147, Fax +965 532 6049, E-Mail johnbowley@hsc.kuniv.edu.kw 
Table 1. The total average cost (irrespective of payment system) and $50 \%$ survival time in years (with reference to the available literature) of replacing one tooth according to the treatment approach

\begin{tabular}{llllc}
\hline Treatment & $\begin{array}{l}\text { Indexed } \\
\text { cost }\end{array}$ & $\begin{array}{l}50 \% \text { survival } \\
\text { time, years }\end{array}$ & $\begin{array}{l}\text { Cost/year } \\
\text { of service }\end{array}$ & $\begin{array}{c}\text { Cost } \\
\text { rank }^{2}\end{array}$ \\
\hline Single-tooth implant & 1.6 & $20[2,3]^{3}$ & 0.080 & 1 \\
Acrylic-resin RPD & 0.2 & $3[4]$ & 0.067 & 2 \\
Metal-frame RPD & 0.5 & $8[4]$ & 0.063 & 3 \\
Adhesive 3-unit FPD & 0.5 & $10[7]$ & 0.050 & $4^{4}$ \\
Metal-ceramic FPD & 1.0 & $20[5,6]$ & 0.050 & $4^{4}$ \\
\hline
\end{tabular}

The 3-unit metal-ceramic FPD is used as index 1 in comparison with other alternatives, and the costs are given for Denmark, the Netherlands and Sweden in 1994 (expansion of Jemt et al. [1]).

Indexed cost divided by $50 \%$ survival time (years).

2 Rank of cost/year: 1 = most expensive, $4=$ least expensive.

Extrapolation based on available clinical studies [2,3].

Two procedures tied for least expensive procedure cost/year.
A patient's oral health status can be categorized along a continuum from optimal dental health through various levels of gradually worsening dental deterioration. This continuum extends from the dentate adult with a complete complement of natural teeth to the totally edentulous state. Deterioration can continue further, from the edentulous state to an end-state of severe residual ridge resorption. Advancing age and worsening medical conditions can complicate all of the various stages of dental health deterioration.

\section{Rate of Disease versus Normal Age-Related Changes}

Dentition wears down as a result of loss of enamel and dentin during mastication and other physiologic functions throughout the life cycle. Any discussion of the incidence of a disease and its relative rate of progression in a society should be compared to the normal rate of breakdown as a result of age in an otherwise healthy population. Because of increasing life expectancy throughout the world, a society must evaluate dental disease in the senior population who remained free of dental complications but became threatened with compromised dentitions late in life. Most societies will continue to experience growth in the population group over the age of 65 years, and this cohort will have increasingly complex dental needs.

The rate and the state of oral disease in a patient at any moment in time must be balanced with a benefit-to-risk ratio when choosing a treatment procedure. Every prosthodontic intervention carries a benefit-to-risk ratio that must be compared with the rate of progression of the disease, the current state of the disease and any risks associated with 'nonintervention treatment'. To meet those considerations, various treatment options are possible: (1) no treatment, (2) one or more low-level prosthodontic interventions or (3) one or more advanced-level prosthodontic interventions. For example, if a mandibular first molar tooth is lost, the clinician might compare the consequences of nontreatment to a low-level prosthodontic treatment intervention (e.g. transitional removable prosthesis) to an advanced-level prosthodontic intervention (e.g. metal-ceramic fixed prosthesis).

Based on published reports [1-6], Owall et al. [7] concluded that a transitional removable partial denture (RPD) has a 3-year 50\% survival rate compared to 20 years for the metal-ceramic fixed partial denture (FPD). A cost comparison of these two procedures is illustrated in table 1. An initial evaluation of cost reveals that the transitional RPD is less than half the cost of an FPD. However, the data in table 1 demonstrate a significant 'reduced cost per year' for the more advanced prosthodontic intervention, the metal-ceramic FPD. Thus, the patient and the society can experience a higher-valued service at a reduced cost with the FPD. In addition to the cost factor analysis, there are negative consequences associated with nontreatment and the low-level transitional RPD that will be discussed further.

\section{Societal Influences on Need versus Demand for \\ Prosthodontic Care}

Each society must determine the current overall dental health of the population when deciding on the desired future level of dental health and how to achieve it. If the societal treatment needs are high, with a low supply of health care providers, the government must consider 
facilitating infrastructure development to foster the maturation of a developing dental health care system. Without governmental facilitation the maturation process will be slow, particularly if there is an absence of existing skilled personnel or attractive incentives [8-14].

To complicate the evolution-maturation process, the needs and demands of professional services within a society must be considered. Treatment needs do not necessarily translate directly into demand for all types of care, as shown in studies of different population groups within the USA. Strauss [15] studied large numbers of AfricanAmericans' feelings about their present dental health status compared to past sentiment using a survey instrument called the Dental Impact Profile. This study reported that many African-Americans were happier in their edentulous state with prostheses than they were in their previous dentate condition; these findings were in contrast to those of the Caucasian counterparts. Strauss revealed distinct patterns of dental health care utilization and patient selfperceived expectations based on demographic factors, race, culture and socioeconomic status. These findings demonstrate that variations among different population groups within the same society must be taken into account in developing countries when planning health care delivery systems.

Certain societies may place a very low priority on the dental health of their population with little or no assignment of governmental resources to facilitate or provide care to address this need. Such a society may emphasize individual responsibility with the expectation that the private resources of citizens would be used to meet dental needs. Obviously, a developing country may not realistically expect its population to be able to afford dental care on their own. If a developing nation's society has a relatively poor state of dental health, prosthodontic needs will vary, and the objective of national oral health care would be to treat the greatest number of citizens with a realistic resource allocation.

\section{Prosthodontic Care Delivery and Human Resource \\ Issues}

A society's need for prosthodontic care is balanced by its demand for this care; the demand, in turn, influences the supply of technical and professional human resources in the health care system. Ideally, a complete health care system would include an adequate number of trained prosthodontic specialists and dental laboratory technicians. Owall et al. [7] illustrated the obstacles encountered in developing nations when attempting to provide this complex level of care because of human resource limita-
Table 2. Countries with legally accepted denturism, based mainly on information courtesy of the Fédération Dentaire Internationale/ World Dental Federation, 1990 [1]

\begin{tabular}{lrc}
\hline Country & $\begin{array}{l}\text { Number of } \\
\text { dentists }\end{array}$ & $\begin{array}{l}\text { Number of } \\
\text { denturists }\end{array}$ \\
\hline Australia & 6,897 & 607 \\
Barbados & 34 & 3 \\
Canada & 13,623 & 2,700 \\
China (People's Republic) & 11,044 & 400 \\
Denmark & 5,100 & 550 \\
Finland & 4,225 & 350 \\
Iran & 3,500 & 2,000 \\
Kiribati & 1 & 2 \\
Morocco & 170 & $2,000^{1}$ \\
The Netherlands & 7,000 & 200 \\
Pakistan & 2,127 & 7,000 \\
USA & 12,000 & 350 \\
Vietnam & 1,594 & 1,000 \\
\hline
\end{tabular}

1 Unqualified dentists who fit dentures.

2 Ariz., Colo., Idaho, Me., Md., Oreg., Wash. (total for 7 of 50 states).

tions. In the cited countries, needs were very high, but the technical expertise available was very low; improvement in the situation would require many years of infrastructure development by educational institutions, government investment and the society's sustained demand.

In a study of developing countries in Africa, Ana [9] reported general practitioner-to-population ratios of 1 to 111,000 in Senegal and 1 to 1,935,000 in Chad Republic. The sheer magnitude of the patient population with high prosthodontic treatment needs can overwhelm a health care system and preclude even minimal prosthodontic intervention. The central problem facing many such societies is a minimal number of professional caregivers coupled to a society with tremendous treatment needs.

Numerous health care delivery systems have tried to expand the capabilities of paraprofessional personnel to make increased services available and decrease governmental costs. One major area within dentistry in which this has been attempted is through the expanded duties of dental technicians. This system modification has allowed dental technicians to provide direct patient care as 'denturists' as well as perform the laboratory fabrication procedures for complete and partially removable prostheses. Table 2 lists countries where this has been attempted [7]. Some advanced countries, such as Canada and the Netherlands, have implemented various forms of 'denturism' 
in the hope of reducing the costs of prosthodontic care. This change in scope of practice among the dental care delivery team has not been as widespread in the USA. The greatest number of studies of this phenomenon in the prosthodontics literature represents the Canadian experience [16-34].

Although controversial, the data suggest an apparent general trend of lower-quality prostheses, increasing costs of other treatments, such as periodontal procedures, and an increased rate of retreatment with lower patient satisfaction. A developing country must carefully evaluate this health care approach with consideration of the negative results documented in the literature.

\section{Societal Prosthodontic Care Planning}

A developing country must view prosthodontic care for the population according to three distinct time frames when planning a dental health care strategy. The time frames include: (1) immediate prosthodontic treatment needs in the first 5 years; (2) the intermediate period of $5-20$ years and (3) the long-term period of greater than 20 years. The immediate period of the first 5 years will inevitably be the most difficult, with very high treatment needs and minimal resources.

During the first time frame, prioritization should allocate resources to the most deserving and serious patient conditions. Primary resource allocation can be assigned to treat completely edentulous patients first, due to the significant dental handicap endured by these individuals and with relatively low treatment cost to society. Subsequent priorities can be incrementally assigned to other patients according to the country's resources and perceptions of oral health. Owall et al. [7] have cited Swedish National Dental Insurance data from 1977 demonstrating a disproportionate advanced level of care to a small percentage of the population. Thus, a disproportionate allocation of resources is common even in the socialized systems of developed countries with highly advanced health care systems.

Intermediate and long-term plans should reap the rewards of significant changes in the population's prosthodontic treatment needs as a result of preventive measures instituted in earlier years. The preventive measures for caries and periodontal disease reduction will reduce the need among the population for prosthodontic care. However, a careful health care planner should avoid overly optimistic expectations from preventive measures. In 1984, Stamm [35] suggested that prevention of periodontal disease has been poor in both developed as well as developing countries. However, once the population has reached this phase, the development and maturation of the dental profession should have progressed to the point where it is more capable of managing the population's reduced prosthodontic treatment needs.

\section{Clinical Decision Analysis and Informed Consent}

To begin the process of assessment, it will be assumed that preventive and/or conservative/operative dentistry procedures have been totally absent or have failed to halt the progression of the process of tooth decay or loss. The first stage along the continuum of dental breakdown might be the large carious lesion with irreversible pulpal pathology in an otherwise intact dentition or advanced periodontal destruction of the supporting structures of a single tooth.

A clinical decision analysis [36, 37] would include two basic options for treatment of the single affected tooth: extraction or restorative therapy with endodontic and periodontal adjunctive therapy, respectively. In a health care delivery system with minimal treatment options, this tooth would be extracted with no further treatment because advanced therapeutic procedures involve cost factors many times greater than that of the single-visit extraction.

The standard of care in advanced, industrialized countries [36, 37] should be used as a starting point for discussion of this aspect of patient management. Due to legal and ethical considerations in the developed countries, the standard of care demands that the clinician provider should present all relevant treatment options, regardless of their resource allocation, complexity, availability or location. This ethical obligation can be somewhat general and may not be within the capabilities of the individual provider but may include a referral recommendation to a tertiary level of care. The nonintervention and minimal prosthodontic intervention (low-level prosthodontic treatment) are two treatment options that should always be accompanied with an explanation of hazards, limitations and risk.

\section{Shortened Dental Arch Concept}

The loss of some natural posterior teeth, and the study of related maladies or side effects, has become known in the literature as the shortened dental arch (SDA) concept. A significant number of citations have appeared in the prosthodontic literature related to SDA and its consequences [38-53]. This body of literature has introduced and evaluated the SDA treatment goal of retaining a limited number of natural teeth without prosthetic replacement. These citations have documented the patient feel- 
ings and levels of satisfaction, as well as undesirable sequelae as compared to patients with prosthetically restored dentitions. The literature suggests that a minimum of four pairs of posterior tooth contacts are necessary for adequate masticatory function, although the specific combination of contacting teeth has not been recommended.

\section{Reduction of Chewing Efficiency}

As a result of the initial minimal intervention procedures of SDA tooth extraction, degradation of dental health is not necessarily halted: the literature has demonstrated varying consequences of tooth loss which further compromise a patient's long-term dental health. The first consequence of the loss of a single tooth is a significant drop in site-specific chewing efficiency.

In the literature [42-46, 54-120], chewing efficiency has been quantified by several different methods, along with other factors such as the swallow threshold and salivary output. Measurement of chewing efficiency remains a relatively controversial topic due to methodological variability. The literature reveals two major methods of assessment: the participants' feelings about their ability to masticate and measures of the pulverization of a test food in a set time period. These two methods can lead to vastly different results; patients may feel that they can masticate adequately with their compromised dentitions but demonstrate a greatly reduced ability to pulverize the test food.

A loss of only the mandibular first molar tooth in a young, healthy dentate patient can cause a $40 \%$ reduction in chewing efficiency [113]. Nonetheless, the SDA concept has been substantiated by studies of the participants' assessment that indicate they would be satisfied with the greatly reduced chewing efficiency that accompanies tooth loss [42-46, 120-124].

\section{Tooth Changes with Adjacent/Antagonist Loss}

Subsequent secondary tooth migration of the adjacent second molar into the edentulous space is a common side effect of first molar tooth loss. The opposing maxillary first molar often erupts because of the absence of its opposing occlusal contact. This positional shift can lead to furcation involvement, elongation of the bony segment and pseudoperiodontal pocket formation, as well as protrusive occlusal interferences in eccentric mandibular movements. Unfortunately, no evidence exists in the literature to help clinicians predict whether these common side effects of tooth loss will or will not occur. One recent study has suggested that molar shift is uncommon [125]. Nevertheless, correction of these compensatory changes when they do occur requires tremendous resources compared to preventive prosthodontics at the time of tooth loss.

\section{Tooth Wear Rate and Fracture}

Tooth wear and fracture occur at some rate in normal function throughout life but appear to accelerate with advancing age. Johansson et al. [126] found a complex interaction between multifactorial etiologic factors and age. Tooth wear occurs at varying rates in patients based on the number of teeth, restoration material types, brushing activity and dietary considerations.

As the number of teeth lost increases, the wear rate to the remaining teeth also increase proportionately: the possible acceleration of this process is due to the overloading of remaining teeth. The increased load per tooth also causes abnormally high stress to the periodontal apparatus which can lead to cusp fracture. In a recently published study [125] on tooth wear and fracture rates in the USA, approximately one quarter of the study population had tooth fractures caused by normal function during a 24-month period. This type of worsening dental health demonstrates the acceleration of deterioration that can occur within a population and places further challenges on a developing country's planning strategy.

\section{Loss of Vertical Dimension of Occlusion and Other Secondary Changes}

As posterior teeth are lost, a decrease in vertical dimension of occlusion can occur in the partially edentulous patient. Excessive loading occurs on the remaining anterior teeth with secondary changes in anterior tooth position, periodontal support and mobility. A common intraoral structural change that accompanies loss of multiple posterior teeth is tongue enlargement due to increased function in chewing.

\section{Transitional RPD}

The Glossary of Prosthodontic Terms (GPT-7, 1999) [127, p 124] defines a transitional partial denture as 'a removable partial denture serving as an interim prosthesis to which artificial teeth will be added as natural teeth are lost and that will be replaced after postextraction tissue changes have occurred'. This prosthesis, generally, has the following attributes: wire clasp direct retainers, acrylic resin base and major connector components with artificial teeth. This type of prosthesis is classified as interim only, chiefly because of its lack of vertical support with poor load distribution, a lack of major connector strength and rigidity, and excessive tissue coverage. Because of 
these three drawbacks, this type of prosthesis is designed for short-term use only, perhaps 3 months or less.

The lack of vertical support can cause excessive load distribution to the edentulous ridge area(s) instead of additional load distribution to as many remaining natural tooth abutments as possible. Additionally, the lingual aspects of many remaining natural teeth are covered to distribute the load to a wider area as well as provide additional direct retention in tooth undercuts. Another significant disadvantage to this type of prosthesis is additional thickness of acrylic resin material to make the major connector as rigid as possible. The combination of excessive bulk and additional tissue coverage contributes to significant potential adverse tissue effects.

Numerous studies have demonstrated the ill effects of different types of acrylic resin materials on epithelial cells of the gingival complex. A developing society should be extremely careful in utilizing this type of prosthesis as a minimal prosthodontic treatment intervention because of its well-documented negative dental health effects. This type of prosthesis may appear to require less societal resources with reduced clinician treatment time and only a preliminary irreversible hydrocolloid impression step. Often, the prosthesis is delivered at the next visit with a reduced laboratory cost because the costly fabrication of a cast metal framework is not required. No published studies have demonstrated data in the literature to support the superiority of this type of prosthesis compared with nonintervention or conventional RPD treatment.

Owall et al. [7] have cited studies [10-15] in the prosthodontic literature demonstrating the indexed cost and $50 \%$ survival rates for transitional RPD, RPD with a cast metal framework, various types of 3-unit FPDs and single-tooth endosseous implant restoration. The transitional RPD is $40 \%$ less expensive than a cast metal RPD, with a survival rate of 3 years based on data from several northern European countries. Initial evaluation of the data indicates that the transitional RPD appears to be the least expensive, with a 3 -year survival rate. However, this cost analysis fails to point out that the 3-unit metal-ceramic FPD has a cost factor of only 5 times the transitional RPD prosthesis but a survival rate 7 times longer. The society would have to replace the transitional RPD approximately 7 times in the same period in $50 \%$ of the population with a $34 \%$ increase in cost. In addition, with each successive replacement of the transitional RPD, there is potential for further deterioration of the remaining dentition because of the factors previously discussed.

The literature [128-132] has shown the ill effects of the close proximity of the acrylic resin of the transitional
RPD to the free gingival margin. Porosity and water sorption foster bacterial colonization on the surface as well as within the material. Hayashi [132] has, with electron microscopy, demonstrated the accumulation of mineralized calculus on the intaglio surface of acrylic resin base material. This proclivity for bacterial colonization and mineral deposition in the form of calculus adjacent to the gingival tissues increases the insult to these tissues. Clinicians of developing countries should avoid utilizing transitional RPDs for prolonged periods in lieu of more advanced prosthodontic procedures, namely conventional RPD with cast metal framework or FPD.

\section{Environmental Hazards and Health Care Planning for Prosthodontic Care}

The number of studies demonstrating the toxicity of acrylic resins has been increasing [133-145]. The literature has shown mounting evidence of the health threat of these prosthetic materials as environmental, biological and chemical hazards. An alarming incidence of occupational health risks to dental clinical and laboratory health personnel has surfaced in the literature [134, 135, 145]. A published case report [133] of respiratory pathology in a dental student, resulting from inhalation of acrylic resin particulate matter, has caused concern about the handling of these contaminated materials within the clinical as well as the laboratory environment. Two case reports of dental technicians with generalized peripheral neuropathy from inhalation of volatilized acrylic resin liquid monomer in a laboratory setting have also been reported [131, 145]. These incidents demonstrate the necessity that dental health care planners insist on the proper use of these materials, with strict adherence to environmental hazards control through negative-pressure vacuum systems and proper ventilation.

Planners must incorporate advanced environmental control systems to protect clinicians and laboratory personnel. This issue is of particular importance to developing countries because of the high utilization rate of acrylic resin materials in low-level prosthodontic treatment procedures. A high utilization rate of acrylic resin, combined with a lack of occupational laboratory environmental standards, would render health care providers and support personnel particularly vulnerable to the occupational hazards cited above.

\section{Edentulous Maxillae and Partially Dentate Mandible Combination}

The SDA concept should be evaluated very carefully in the patient with an edentulous maxilla opposing a partial- 
ly edentulous Kennedy class I mandible with few posterior natural teeth remaining. The unrestored mandible will induce residual ridge resorption in the anterior premaxilla as a result of differential loading of the maxillary prosthesis by the remaining natural teeth. This is a relatively common side effect described as the combination syndrome (also called anterior hyperfunction syndrome). Other side effects of this imbalance of forces include hyperplasia of the posterior edentulous tuberosity, pneumatization of the bony down-growth and papillary hyperplasia [127, p. 134]. The application of the SDA concept would be contraindicated in this specific situation because of these side effects, which have been shown to occur in patients with Kennedy class I RPD restorations (called Kelly's syndrome when it occurs in conjunction with mandibular Kennedy class I RPD) [127, p. 74]. In 1972, Kelly [146] reported that these side effects could occur if patients were not properly managed with followup relining procedures and routine professional recall care.

\section{Conclusion}

This literature review was performed to analyze the needs of developing countries when planning future prosthodontic care. Of central importance to health care infrastructure planning is determining what a society's actual requirements are. It is necessary to first undertake some evaluation of the patients' needs and expectations and to do so on a broad basis as these elements may differ across populations depending on factors ranging from cultural to racial differences. Early stages of the planning process and resource allocation should attend to both human resource development and preventive modalities; these aspects of prosthodontic care planning can be divided into three separate time periods based on result orientation and need: (1) first 5 years, (2) 5-20 years and (3) 20 years or greater. While short-term planning can address itself to immediate suffering and preventive approaches to dental diseases, longer-term planning must examine the issues of developing skilled technical staff to deal with future needs. It should also be noted that the world population demographic is increasing in age as life expectancy increases and health care systems must be prepared for the greater dental care needs of this increasingly aged population.

Several treatment and infrastructure possibilities were also examined. While many developed nations have undertaken a system expansion technique known as den- turism, the cited literature identified several negative impacts on the quality and cost of care and would strongly caution against this approach. As well, the literature noted some strong benefit-risk developments associated with the choice between nonintervention, transitional RPD and advanced level prosthodontic treatment. Some of the risks associated with transitional RPDs include: (1) bacterial colonization of porous material adjacent to gingival tissues, (2) excessive bulk to increase strength, (3) lack of vertical support and (4) excessive suprabulge tooth coverage for stability, direct retention and reciprocation. As a result, the transitional RPD should never be utilized for more than 3 months. The choice of intervention involves important cost considerations, and factors such as the life expectancy of RPDs should be fully analyzed.

There has also been some concern raised about the safety of acrylic resin monomer and patient-contaminated particulate matter. Developing countries need to take particular care to manage the safety of laboratory and clinical personnel if technically skilled staff is to be recruited and retained. It is necessary to balance limited resources with the fundamental needs of long-term dental infrastructure building and staff safety.

As noted, the dental care requirements of a population are largely dependent on their perceived needs and personal satisfaction with care. Nevertheless, patients need to be provided with the information necessary to make informed consent, and some details of clinical analysis and possible intervention, or nonintervention, should be made available to them. For example, some countries have embraced the SDA concept, which accepts a threshold level of dentition loss. Patients and provides need to be aware that possible significant negative effects of this protocol include: (1) reduced chewing efficiency, (2) tooth positional changes such as eruption or horizontal drifting, (3) increased tooth wear and fracture, (4) loss of vertical dimension of occlusion and (5) physiologic overload on the remaining periodontium. Again, consultation on thresholds for treatment is a societal issue and should be addressed as such.

It is necessary to build infrastructure by proper planning and understanding of population needs. The issues of prosthodontic planning are issues of human resources and the examination of the outcomes of interventions which most effectively achieve the goal of a healthy citizenry. Government planning, facilitation and investment must be undertaken with care if developing nations are to look forward to a healthy future. 


\section{References}

1 Jemt J, Lekholm U, Grondahl K: 3-year followup study of early single implant restorations ad modum Branemark. Int J Periodontics Restorative Dent 1990;10:340-349.

2 Laney WR, Jemt T, Harris D, Henry PJ, Krogh PHJ, Polizzi G, Zarb GA, Hermann I: Ossointegrated implants for single-tooth replacement: Progress report from a multicenter prospective study after three years. Int J Oral Maxillofac Implants 1994;9:49-54.

3 Vermeulen A: Een decennium evaluatie van partiele prosthesen. Eeen beschrijvend klinisch longitudinal onderzoek; thesis University of Nijmegen, 1984.

4 Creugers NH, van't Hof MA: An analysis of clinical studies on resin-bonded bridges. J Dent Res 1991;70:146-149.

5 Creugers NL, van't Hof MA: A seven-and-ahalf year survival study of resin-bonded bridges. J Dent Res 1992;71:1822-1825.

6 Creugers NH, Kayser AF, van't Hof MA: Metaanalysis of durability data on conventional fixed bridges. Community Dent Oral Epidemiol 1994;22:448-452.

7 Owall B, Kayser AF, Carlsson GE: Prosthodontics Principles and Management Strategies, ed 1. Barcelona, Mosby-Wolfe, 1996.

8 Songpaisan Y: Manpower and the future role of dentistry in developing countries. Int Dent $\mathbf{J}$ 1985;35:78-82.

9 Ana JR: Dental manpower needs in a developing community: A critical analysis of the West African scene. Int Dent J 1976;26:41-420.

10 Hunter JM, Arbona SI: The tooth as a marker of developing world quality of life: A field study in Guatemala. Soc Sci Med 1995;41: 1217-1240.

11 Bezroukov V: Dental education in the developing countries and the role of WHO. Int Dent $\mathrm{J}$ 1977;27:18-24.

12 Dickson M: Managing common oral problems: Some considerations. Trop Doct 1991;21:1316.

13 Anumanrajadhon T, Rajchagool S, Nitisiri P, Phantumvanit P, Songpaisan Y, Barmes DE, Sardo-Infirri J, Davies GN, Moller IJ, Pilot T: The community care model of the Intercountry Centre for Oral Health at Chiangmai, Thailand. Int Dent J 1996;46:325-333.

14 Barmes DE: The worldwide distribution and significance of oral diseases. Int Dent J 1977; 27:270-272.

15 Strauss RP: The dental impact profile; in Slade GD (ed): Measuring Oral Health and Quality of Life. Chapel Hill, University of North Carolina, 1997, pp 81-91.

16 Rantanen T, Kononen M: Dentist and dental technicians as competing suppliers of complete dentures in Southwest Finland. Community Dent Oral Epidemiol 1979;7:270-273.

17 Waldman HB: The reaction of the dental profession to changes in the 1970s. Am J Public Health 1980;70:619-624.
18 Rosenstein DI, Joseph LP, Mackenzie LJ, Wyden R: Professional encroachment: A comparison of the emergence of denturists in Canada and Oregon. Am J Public Health 1980;70: 614-618.

19 Dussault G: Dental services in Quebec: Issues and changes. Soc Sci Med 1984;18:251-255.

20 Rosenstein DI, Empey G, Chiodo GT, Phillips D: The effects of denturism on denture prices. Am J Public Health 1985;75:671-672.

21 Lewis DW: Economic considerations in geriatric oral health care: The Canadian experience. Health Matrix 1988;6:29-35.

22 Heloe LA: Comparative policies of two national dental associations: Norway and the United States. J Public Health Policy 1991;12:209228.

23 Lewis DW, Thompson GW: Utilization in Alberta's universal dental plan for the elderly, 1974-1991. J Public Health Dent 1992;52: 259-263.

24 Jennen RP: Denturists legalized in the Netherlands. EDS Mag 1992;3:21-23.

25 Friedrichsen SW, Herzog AE, Christie CA: A socioeconomic comparison of patients receiving prostheses in a two-tier delivery system. $\mathrm{J}$ Prosthet Dent 1992;67:348-357.

26 MacEntee MI: Biologic sequelae of tooth replacement with removable partial dentures: A case for caution. J Prosthet Dent 1993;70:132134.

27 MacEntee MI: Denturists and oral health in the aged. J Prosthet Dent 1994;71:192-196.

28 Thompson GW, Lewis DW: Changes in utilization of dental services of Alberta's universal dental plan for the elderly. J Can Dent Assoc 1994;60:403-406.

29 Lewis DW, Thompson GW: Continuity of dental treatment by users of Alberta's universal dental plan for the elderly. J Can Dent Assoc 1994;60:419-421.

30 Lewis DW, Thompson GW: Alberta's universal dental plan for the elderly: Differences in use over 6 years by two cohorts. Am J Public Health 1995;85:1408-1411.

31 Wolfaardt JF, Tan HK, Basker RM: Removable partial denture design in Alberta dental practices. J Can Dent Assoc 1996;62:637-644.

32 Lewis DW, Thompson GW: A comparison of moderate and high users of Alberta's universal dental plan for the elderly. J Can Dent Assoc 1996;62:938-941, 944-945.

33 Abrams SH: Denturists: Do they really provide more affordable care in Ontario? J Can Dent Assoc 1997;63:771-774.

34 Morin C, Lund JP, Sioufi C, Feine JS: Patient satisfaction with dentures made by dentists and denturologists. J Can Dent Assoc 1998;64: 205-208, 210-212.

35 Stamm JW: Achievements in prevention. Int Dent J 1984;34:66-72.

36 Bowley JF, Stockstill JW, Attanasio R: A preliminary diagnostic and treatment protocol. Dent Clin North Am 1992;36:551-568.

37 Stockstill JW, Bowley JF, Attanasio R: Clinical decision analysis in fixed prosthodontics. Dent Clin North Am 1992;36:569-580.
38 Kayser AF: Shortened dental arches and oral function. J Oral Rehabil 1981;8:457-462.

39 Witter DJ, van Elteren P, Kayser AF: Migration of teeth in shortened dental arches. $\mathrm{J}$ Oral Rehabil 1987;14:321-329.

40 Kayser AF: Shortened dental arch: A therapeutic concept in reduced dentitions and certain high-risk groups. Int J Periodontics Restorative Dent 1989;9:426-449.

41 Kayser AF, Meeuwissen R, Meeuwissen JH: An occlusal concept for dentate geriatric patients. Community Dent Oral Epidemiol 1990; 18:319.

42 Witter DJ, Cramwinckel AB, van Rossum GM, Kayser AF: Shortened dental arches and masticatory ability. J Dent 1990;18:185-189.

43 Kayser AF: How much reduction of the dental arch is functionally acceptable for the aging patient? Int Dent J 1990;40:183-188.

44 Witter DJ, Van Elteren P, Kayser AF, Van Rossum GM: Oral comfort in shortened dental arches. J Oral Rehabil 1990;17:137-143.

45 Witter DJ, De Haan AF, Kayser AF, Van Rossum GM: Shortened dental arches and periodontal support. J Oral Rehabil 1991;18:203212.

46 Van Waas MA, Meeuwissen JH, Meeuwissen R, Kayser AF: Oral function in dentate elderly with reduced dentitions. Gerodontology 1993; 10:40-43.

47 Kalk W, Kayser AF, Witter DJ: Needs for tooth replacement. Int Dent J 1993;43:41-49.

48 Witter DJ, De Haan AF, Kayser AF, van Rossum GM: A 6-year follow-up study of oral function in shortened dental arches. I. Occlusal stability. J Oral Rehabil 1994;21:113-125.

49 Witter DJ, De Haan AF, Kayser AF, Van Rossum GM: A 6-year follow-up study of oral function in shortened dental arches. II. Craniomandibular dysfunction and oral comfort. J Oral Rehabil 1994;21:353-366.

50 Meeuwissen JH, van Waas MA, Meeuwissen R, Kayser AF, van't Hof MA, Kalk W: Satisfaction with reduced dentitions in elderly people. J Oral Rehabil 1995;22:397-401.

51 Allen PF, Witter DF, Wilson NH, Kayser AF: Shortened dental arch therapy: Views of consultants in restorative dentistry in the United Kingdom. J Oral Rehabil 1996;23:481-485.

52 Witter DJ, Allen PF, Wilson NH, Kayser AF Dentists' attitudes to the shortened dental arch concept. J Oral Rehabil 1997;24:143-147.

53 Kayser AF: Limited treatment goals - Shortened dental arches. Periodontal 2000 1994;4: 7-14.

54 Agerberg G, Carlsson GE: Chewing ability in relation to dental and general health: Analyses of data obtained from a questionnaire. Acta Odontol Scand 1981;39:147-153.

55 Akeel R, Nilner M, Nilner K: Masticatory efficiency in individuals with natural dentition. Swed Dent J 1992;16:191-198.

56 Albrektsson T, Blomberg S, Branemark A, Carlsson GE: Edentulousness - An oral handicap: Patient reactions to treatment with jawbone-anchored prostheses. J Oral Rehabil 1987;14:503-511. 
57 Aukes JN, Kayser AF, Felling AJ: The subjective experience of mastication in subjects with shortened dental arches. J Oral Rehabil 1988; 15:321-324.

58 Bakke M, Hoom B, Jensen BL, Michler L, Moller E: Unilateral, isometric bite force in 8to 68-year-old women and men related to occlusal factors. Scand J Dent Res 1990;98:149_ 158.

59 Bates JF, Stafford GD, Harrison A: Masticatory function - A review of the literature. III Masticatory performance and efficiency. J Oral Rehabil 1976;3:57-67.

60 Budtz-Jorgensen E, Isidor F: Cantilever bridges or removable partial dentures in geriatric patients: A two-year study. J Oral Rehabil 1987; 14:239-249.

61 Carlson BR, Carlsson GE, Helkimo E, Yontchev E: Masticatory function in patients with extensive fixed cantilever prostheses. J Prosthet Dent 1992;68:918-923.

62 Carlsson GE: Masticatory efficiency: The effect of age, the loss of teeth and prosthetic rehabilitation. Int Dent J 1984;34:93-97.

63 Christiansen EG: Note on 'chewing power of teeth'. Br Dent J 1924;45:318.

64 Edlund J, Lamm CJ: Masticatory efficiency. J Oral Rehabil 1980;7:123-130.

65 Floystrand F, Kleven E, Oilo G: A novel miniature bite force recorder and its clinical application. Acta Odontol Scand 1982;40:209-214.

66 Graf H, Grassl H, Aeberhard HJ: A method for measurement of occlusal forces in three directions. Helv Odontol Acta 1974;18:7-11.

67 Gunne HS, Bergman B, Enbom L, Hogstrom J: Masticatory efficiency of complete denture patients. A clinical examination of potential changes at the transitions from old to new denture. Acta Odontol Scand 1982;40:289-297.

68 Gunne HS: Masticatory efficiency: A new method for determination of the breakdown of masticated test material. Acta Odontol Scand 1983;41:271-276.

69 Gunne HS: Masticatory efficiency and dental state: A comparison between two methods. Acta Odontol Scand 1985;43:139-146.

70 Gunne HS, Wall AK: The effect of new complete dentures on mastication and dietary intake. Acta Odontol Scand 1985;43:257-268.

71 Gunne HS: The effect of removable partial dentures on mastication and dietary intake. Acta Odontol Scand 1985;43:269-278.

72 Haraldson T: Comparisons of chewing patterns in patients with bridges supported on osseointegrated implants and subjects with natural dentitions. Acta Odontol Scand 1983;41:203208.

73 Haraldson T, Carlsson GE: Chewing efficiency in patients with osseointegrated oral implant bridges. Swed Dent J 1979;3:183-191.

74 Haraldson T, Carlsson GE, Ingervall B: Functional state, bite force and postural muscle activity in patients with osseointegrated ora implant bridges. Acta Odontol Scand 1979;37 195-206.
75 Haraldson T, Ingervall B: Muscle function during chewing and swallowing in patients with osseointegrated oral implant bridges: An electromyographic study. Acta Odontol Scand 1979;37:207-216.

76 Haraldson T, Jemt T, Stalblad PA, Lekholm U: Oral function in subjects with overdentures supported by osseointegrated implants. Scand J Dent Res 1988;96:235-242.

77 Haraldson T, Karlsson U, Carlsson GE: Bite force and oral function in complete denture wearers. J Oral Rehabil 1979;6:41-48.

78 Harle TJ, Anderson JD: Patient satisfaction with implant-supported prostheses. Int J Prosthodont 1993;6:153-162.

79 Heath MR: Dietary selection by elderly persons, related to dental state. Br Dent J 1972; 132:145-148.

80 Heath MR: The effect of maximum biting force and bone loss upon masticatory function and dietary selection of the elderly. Int Dent J 1982; 32:345-356.

81 Helkimo E, Carlsson GE, Helkimo M: Bite force and state of dentition. Acta Odontol Scand 1977;35:297-303.

82 Helkimo E, Carlsson GE, Helkimo M: Chewing efficiency and state of dentition. Acta Odontol Scand 1978;36:33-41.

83 Jemt T: Chewing patterns in dentate and complete denture wearers recorded by light-emitting diodes. Swed Dent J 1981;5:199-205.

84 Jemt T, Carlsson GE: Aspects of mastication with bridges on osseointegrated implants. Scand J Dent Res 1986;94:66-71.

85 Jemt T, Hedegard B, Wickberg K: Chewing patterns before and after treatment with complete maxillary and bilateral distal-extension mandibular removable partial dentures. J Prosthet Dent 1983;50:566-569.

86 Jemt T, Karlsson S: Mandibular movements during mastication before and after rehabilitation with new complete dentures recorded by light-emitting diodes. Swed Dent J 1980;4: 195-200.

87 Jemt T, Stalblad PA: The effect of chewing movements on changing mandibular complete overdentures to osseointegrated overdentures. J Prosthet Dent 1986;55:357-361.

88 Karlsson S, Jemt T: Adaptive changes of masticatory movement characteristics after rehabilitation with osseointegrated fixed prostheses in the edentulous jaw: A 10-year follow-up study. Int J Oral Maxillofac Implants 1991;6:259263.

89 Karlsson S, Persson M, Carlsson GE: Mandibular movement and velocity in relation to state of dentition and age. J Oral Rehabil 1991;18: $1-8$.

90 Kayser AF, van der Hoeven JS: Colorimetric determination of the masticatory performance. J Oral Rehabil 1977;4:145-148.

91 Kent G, Johns R: Controlled longitudinal study on the psychological effects of osseointegrated dental implants. Int J Oral Maxillofac Implants 1991;6:470-474.

92 Kiyak HA, Beach BH, Worthington P, Taylor T, Bolender C, Evans J: Psychological impact of osseointegrated dental implants. Int J Oral Maxillofac Implants 1990;5:61-69.
93 Lindquist LW, Carlsson GE, Hedegard B, Lindquist LW: Changes in bite force and chewing efficiency after denture treatment in edentulous patients with denture adaptation difficulties. J Oral Rehabil 1986;13:21-29.

94 Lindquist LW, Carlsson GE: Long-term effects on chewing with mandibular fixed prostheses on osseointegrated implants. Acta Odontol Scand 1985;453:39-45.

95 Lundgren D, Laurell L: Occlusal force pattern during chewing and biting in dentitions restored with fixed bridges of cross-arch extension. II. Unilateral posterior two-unit cantilevers. J Oral Rehabil 1986;13:191-203.

96 Lundqvist S, Haraldson T: Occlusal perception of thickness in patients with bridges on osseointegrated oral implants. Scand J Dent Res 1984;92:88-92.

97 Mahmood WA, Watson CJ, Ogden AR, Hawkins RV: Use of image analysis in determining masticatory efficiency in patients presenting for immediate dentures. Int $\mathbf{J}$ Prosthodont 1992;5:359-366

98 Mericske-Stern R, Geering AH, Burgin WB Graf $\mathrm{H}$ : Three-dimensional force measurements of mandibular implants supporting overdentures. Int J Oral Maxillofac Implants 1992; 7:185-194.

99 Nakano S, Saitoh M, Yosida Y: Evaluation of masticatory efficiency and the analysis of occlusal factors using a computer-image processing method. Aichi Gakuin Diagaku Shigakkai Shi 1989;27:607-612.

100 Owall B, Moller B: Oral tactile sensibility during biting and chewing. Odontol Revy 1974; 25:327-346.

101 Owall B: Oral tactility during chewing. III. Denture wearers. Odontol Revy 1974;25 255-271.

102 Sandstrom B, Lindquist LW: The effect of different prosthetic restoration on the dietary selection in edentulous patients: A longitudinal study of patients initially treated with optimal complete dentures and finally with tissue-integrated prostheses. Acta Odontol Scand 1987;45:423-428.

103 Slagter AP, Olthoff LW, Bosman F, Steen WH: Masticatory ability, denture quality and oral conditions in edentulous subjects. J Prosthet Dent 1992;68:299-307.

104 Slagter AP, Olthoff LW, Steen WH, Bosman F: Comminution of food by complete-denture wearers. J Dent Res 1992;71:380-386.

105 Slagter AP, van der Glas HW, Bosman F, Olthoff LW: Force-deformation properties of artificial and natural foods for testing chewing efficiency. J Prosthet Dent 1992;68:790799.

106 Slagter AP, Bosman F, van der Bilt A: Comminution of two artificial test foods by dentate and edentulous subjects. J Oral Rehabil 1993;20:159-176.

107 Slagter AP, Bosman F, van der Glas HW, van der Bilt A: Human jaw-elevator muscle activity and food comminution in the dentate and edentulous state. Arch Oral Biol 1993;38: 195-205. 
108 Tzakis MG, Kiliardis S, Carlsson GE: Effect of chewing training on masticatory efficiency. Acta Odontol Scand 1989;47:355-360.

109 Vinton P, Manly RS: Masticatory efficiency during the period of adjustment of dentures. J Prosthet Dent 1955;5:477-480.

110 Wayler AH, Chauncey HH: Impact of complete dentures and impaired natural dentition on masticatory performance and food choice in healthy aging men. J Prosthet Dent 1983; 49:427-433.

111 Yurkstas A: The masticatory act: A review. J Prosthet Dent 1965;15:248-260.

112 Yurkstas A, Curby WA: Force analysis of prosthetic appliances during function. J Prosthet Dent 1953;3:82-87.

113 Yurkstas A: The effect of missing teeth on masticatory performance and efficiency. J Prosthet Dent 1954;4:120.

114 Helkimo E, Carlsson GE, Helkimo M: Chewing efficiency and state of dentition: A methodologic study. Acta Odontol Scand 1978;36: 33-41

115 van der Bilt A, Olthoff LW, Bosman F, Oosterhaven SP: The effect of missing postcanine teeth on chewing performance in man. Arch Oral Biol 1993;38:423-429.

116 Brodeur JM, Laurin D, Vallee R, Lachapelle $\mathrm{D}$ : Nutrient intake and gastrointestinal disorders related to masticatory performance in the edentulous elderly. J Prosthet Dent 1993; 70:468-473.

117 Boretti G, Bickel M, Geering AH: A review of masticatory ability and efficiency. J Prosthet Dent 1995;74:400-403.

118 Ow RK, Loh T, Neo J, Khoo J: Perceived masticatory function among elderly people. J Oral Rehabil 1997;24:131-137.

119 Slade GD, Spencer AJ, Roberts-Thomson K: Tooth loss and chewing capacity among older adults in Adelaide. Aust NZ J Public Health 1996;20:76-82.

120 Gavron G, Volchansky A: Incisor trauma follows early loss of molars. J Dent Assoc S Afr 1997;52:767-768.

121 Shifman A, Laufer BZ, Chweidan H: Posterior bite collapse - Revisited. J Oral Rehabil 1998;25:376-385

122 Liedberg B, Spiechowicz E, Owall B: Mastication with and without removable partial dentures: An intraindividual study. Dysphagia 1995; 10:107-112.
123 al-Ali F, Heath MR, Wright PS: Chewing performance and occlusal contact area with the shortened dental arch. Eur J Prosthodont Restor Dent 1998;6:127-132.

124 Shugars DA, Bader JD, Phillips SW Jr, White BA, Brantley CF: The consequences of not replacing a missing posterior tooth. J Am Dent Assoc 2000;131:1317-1323.

125 Heft MW, Gilbert GH, Dolan TA, Foerster $\mathrm{U}$ : Restoration fractures, cusp fractures and root fragments in a diverse sample of adults: 24-month incidence. J Am Dent Assoc 2000; 131:1459-1464.

126 Johansson A, Haraldson T, Omar R, Kiliaridis S, Carlsson GE: An investigation of some factors associated with occlusal tooth wear in a selected high wear sample. Scand J Dent Res 1993; 101:407-415.

127 Glossary of prosthodontic terms, ed 7 (GPT7). J Prosthet Dent 1999;81:74, 124-134.

128 Goultschin J, Zilberman Y: Gingival response to removable orthodontic appliances. Am J Orthod 1982;81:147-149.

129 Lefebvre CA, Schuster GS, Caughman GB, Caughman WF: Effects of denture base resins on oral epithelial cells. Int $\mathbf{J}$ Prosthodont 1991;4:371-376.

130 Orr S, Linden GJ, Newman HN: The effect of partial denture connectors on gingival health. J Clin Periodontol 1992;19:589-594.

131 Mullally BH, Linden GJ: Periodontal status of regular dental attenders with and without removable partial dentures. Eur J Prosthodont Restor Dent 1994;2:161-163.

132 Hayashi Y: High resolution electron microscopy of the interface between dental calculus and denture resin. Scanning Microsc 1995;9: 419-427.

133 Barrett TE, Pietra GG, Maycock RL, Rossman MD, Minda JM, Johns LW: Acrylic resin pneumoconiosis: Report of a case in a dental student. Am Rev Respir Dis 1989;139: 841-843.

134 Donaghy M, Rushworth G, Jacobs JM: Generalized peripheral neuropathy in a dental technician exposed to methyl methacrylate monomer. Neurology 1991;41:1112-1116.
135 Steendahl U, Prescott E, Damsgaard MT: Methylmethacrylate and organic dementia: A dose-response analysis among dental technicians and opticians. Ugeskr Laeger 1992;154: 1421-1428.

136 Taningher M, Pasquini R, Tanzi MC, Bonatti S: Genotoxicity of N-acryloyl-N'-phenylpiperazine, a redox activator for acrylic resin polymerization. Mutat Res 1992;282:99105.

137 Lefebvre CA, Schuster GS, Richardson DW, Barron DJ: The cytotoxic effects of denture base resin sealants. Int J Prosthodont 1992;5: 558-562.

138 Barron DJ, Schuster GS, Caughman GB, Lefebvre CA: Biocompatibility of visible light polymerized denture base resins. Int J Prosthodont 1993;6:495-501.

139 Lefebvre CA, Schuster GS: Biocompatibility of visible light-cured resin systems in prosthodontics. J Prosthet Dent 1994;71:178-185.

140 Tsuchiya H, Hoshino Y, Tajima K, Takagi N Leaching and cytotoxicity of formaldehyde and methyl methacrylate from acrylic resin denture base materials. J Prosthet Dent 1994; 71:618-624.

141 Lefebvre CA, Knoernschild KL, Schuster GS Cytotoxicity of eluates from light-polymerized denture base resins. J Prosthet Dent 1994;72:644-650.

142 Schuster GS, Lefebvre CA, Dirksen TR, Knoernschild KL, Caughman GB: Relationships between denture base resin cytotoxicity and cell lipid metabolism. Int J Prosthodont 1995;8:580-586.

143 Sheridan PJ, Koka S, Ewoldsen NO, Lefebvre CA, Lavin MT: Cytotoxicity of denture base resins. Int J Prosthodont 1997;10:73-77.

144 Chen MS, Wu JN, Yang SN, Hsieh WY, Liu JC, Fu E, Liu DD: Free radicals are involved in methylmethacrylate-induced neurotoxicity in human primary neocortical cell cultures. Chin J Physiol 1998;41:203-209.

145 Sadoh DR, Sharief MK, Howard RS: Occupational exposure to methyl methacrylate monomer induces generalized neuropathy in a dental technician. Br Dent J 1999;186:380381.

146 Kelly E: Changes caused by a mandibular removable partial denture opposing maxillary complete denture. J Prosthet Dent 1972;27: 140-150. 